\title{
Development and Validation of Stability Indicating RP-HPLC Method for Estimation of Satranidazole from Its Formulation
}

\author{
Harshal Ashok Pawar and Pooja Rasiklal Joshi \\ Dr. L. H. Hiranandani College of Pharmacy, Smt. CHM Campus, Opposite Ulhasnagar Railway Station, \\ Ulhasnagar, Maharashtra 421003, India \\ Correspondence should be addressed to Harshal Ashok Pawar; harshal.dlhhcop@gmail.com
}

Received 27 October 2013; Accepted 1 December 2013; Published 12 January 2014

Academic Editors: A. Sanches Silva and A. Vazquez

Copyright (C) 2014 H. A. Pawar and P. R. Joshi. This is an open access article distributed under the Creative Commons Attribution License, which permits unrestricted use, distribution, and reproduction in any medium, provided the original work is properly cited.

\begin{abstract}
Satranidazole is a new nitroimidazole derivative with potent antiamoebic action and is available in market in the form of tablet and dry syrup either alone or in combination with Ofloxacin. The present study involves the development of simple, accurate, precise, and reproducible reversed phase high performance liquid chromatography (RP-HPLC) method for determination of Satranidazole from its granular dosage form. Isocratic elution at a flow rate of $1.0 \mathrm{~mL} / \mathrm{min}$ was employed on BDS Hypersil C18 $(250 \mathrm{~mm} \times 4.6 \mathrm{~mm}$, $5 \mu \mathrm{m}$ ) column at $25^{\circ} \mathrm{C}$ temperature. The mobile phase consists of $0.16 \% \mathrm{v} / \mathrm{v}$ orthophosphoric acid solution, $\mathrm{pH}$ 3: acetonitrile in the ratio of $60: 40 \mathrm{v} / \mathrm{v}$. The UV detection wavelength was $320 \mathrm{~nm}$, and $20 \mu \mathrm{L}$ sample was injected. The retention time for Satranidazole was about 4.3 minutes. The method was validated for various parameters such as system suitability, precision, recovery, robustness, and ruggedness as per ICH guidelines. The validated RP-HPLC method was found to be specific, linear, precise, and accurate and can be successfully employed for the assay of Satranidazole taste masked granules coated with Eudragit E100 and marketed tablets.
\end{abstract}

\section{Introduction}

Satranidazole (STZ) is a new nitroimidazole derivative with potent antiamoebic action. It is used in the treatment of intestinal and hepatic amoebiasis, giardiasis, trichomoniasis, and anaerobic infections. Its dose is $300 \mathrm{mg}$ twice daily for 3-5 days in the treatment of amoebiasis and $600 \mathrm{mg}$ as a single dose in the treatment of giardiasis and trichomoniasis. It is reported that Satranidazole exhibits significantly higher plasma concentrations than metronidazole and has a plasma elimination half-life of 1.01 hour which is significantly shorter than the corresponding metronidazole half-life of 3.62 hour [1]. Also Satranidazole is having better tolerability, absence of neurological, and disulfiram like reactions and it can be preferred in patients with susceptible neurological symptoms [2]. The structure of STZ is as shown in Figure 1. Literature survey revealed that there are various methods for individual determination of STZ by using RP-HPLC [3], HPLC [4], HPTLC [5, 6], and spectrophotometer [7] and also simultaneous estimation of STZ and Ofloxacin in tablet dosage form $[8,9]$. Satranidazole is not official in any pharmacopoeia and no stability indicating method is reported for determination of Satranidazole in tablets and granular formulations. Hence, the present work was undertaken.

The objective of present study was to develop and validate an accurate, specific, and precise RP-HPLC method for assay of STZ in taste masked granular formulation and tablets. The developed method can be used for analysis of stability samples of Satranidazole tablets and granules.

\section{Materials and Methods}

2.1. Chemicals and Reagents. Satranidazole was obtained as a gift sample from Alkem Laboratories, Mumbai. Eudragit E100 was obtained from Evonik Degussa, Mumbai. Satrogyl tablets (strength: $300 \mathrm{mg}$ ) were purchased from market. All the chemicals and reagents used were of analytical grade. HPLC grade water and solvents were used for HPLC analysis.

2.2. Instrumentation. A double-beam UV-Vis spectrophotometer (Shimadzu, Japan) with $1.0 \mathrm{~cm}$ quartz cells was used 


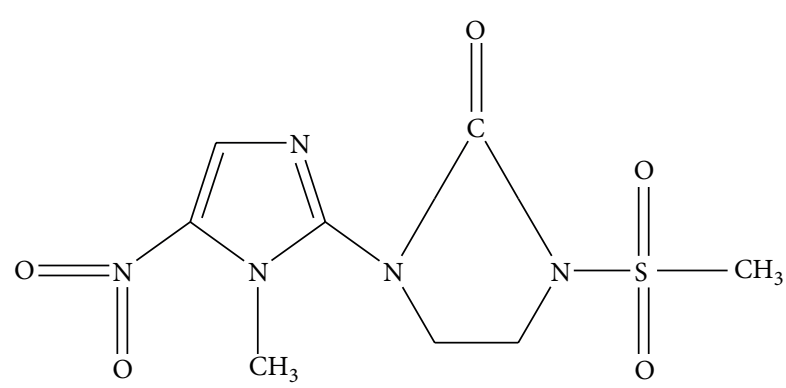

FIGURE 1: Structure of Satranidazole.

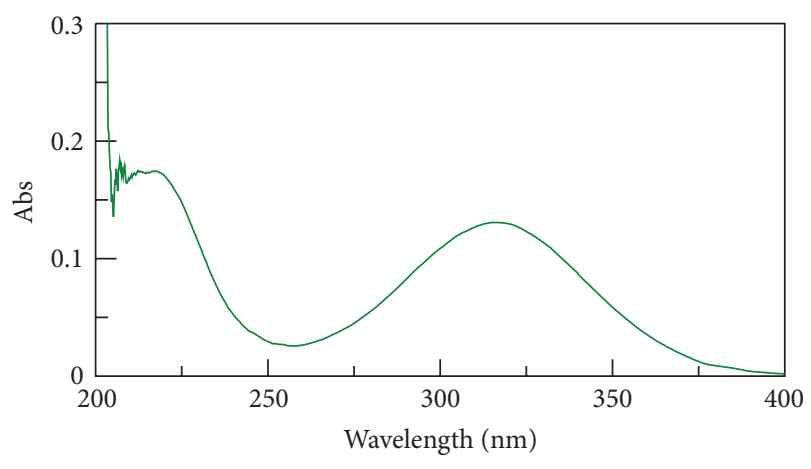

FIgURE 2: UV-spectrum of STZ.

TABLE 1: Factors of robustness study.

\begin{tabular}{lccc}
\hline Parameter & Low & Nominal & High \\
\hline Wavelength $(\mathrm{nm})$ & 318 & 320 & 322 \\
Flow rate $(\mathrm{mL} / \mathrm{min})$ & 0.8 & 1 & 1.2 \\
Temperature $\left({ }^{\circ} \mathrm{C}\right)$ & 20 & 25 & 30 \\
\hline
\end{tabular}

The HPLC parameters were optimized on trial and error basis. The selection of stationary phase depends upon the chemical nature of the sample, solubility, and the molecular weight. Satranidazole is water insoluble compound and hence reverse phase columns was selected. Among C8 and C18, BDS Hypersil C18 column $(250 \mathrm{~mm} \times 4.6 \mathrm{~mm}, 5 \mu \mathrm{m})$ was selected. Various combinations of methanol, acetonitrile, orthophosphoric acid, ammonium dihydrogen phosphate, and triethylamine were tested. Mixture of acetonitrile, $0.16 \%$ v/v Orthophosphoric acid buffer solution, $\mathrm{pH} 3(40: 60 \mathrm{v} / \mathrm{v})$, was selected as mobile phase. The $0.16 \% \mathrm{v} / \mathrm{v}$ Orthophosphoric acid buffer solution was prepared by dissolving $1.6 \mathrm{~mL}$ orthophosphoric acid in water and the $\mathrm{pH}$ of the solution was adjusted to 3.0 using triethylamine. Composition of mobile phase on the retention time of Satranidazole was thoroughly investigated. At this optimized concentration Satranidazole gave symmetric peak with short runtime. UV detection wavelength was $320 \mathrm{~nm}$, flow rate was $1.0 \mathrm{~mL} / \mathrm{min}$, injection volume was $20 \mu \mathrm{L}$, with ambient temperature, runtime was $7 \mathrm{~min}$, and retention time was about $4.3 \mathrm{~min}$.

2.7. Validation of Proposed HPLC Method. The proposed method was validated as per ICH guidelines [10]. The assay method of Satranidazole was validated for linearity, precision, accuracy, specificity, robustness, and solution stability.

2.7.1. Specificity. Blank and placebo solution was injected to check the specificity of method. The specificity of the method was evaluated by comparing the chromatograms of blank, placebo, standard, and sample.

2.7.2. Linearity. Linearity was performed by preparing various concentrations of standard solution of Satranidazole in 
TABLE 2: Comparison of the performance characteristics of the present method with the published methods.

\begin{tabular}{|c|c|c|c|c|c|c|c|}
\hline $\begin{array}{l}\text { S. } \\
\text { number }\end{array}$ & Method/mobile phase & $\begin{array}{c}\text { Column/stationary } \\
\text { phase }\end{array}$ & $\begin{array}{l}\text { Wavelength } \\
(\mathrm{nm})\end{array}$ & $\begin{array}{l}\text { Retention time } \\
(\min )\end{array}$ & Linearity range & Application & $\begin{array}{c}\text { Reference } \\
\text { number }\end{array}$ \\
\hline 1 & $\begin{array}{l}\text { RP-HPLC/acetonitrile: } \\
0.025 \mathrm{M} \\
\text { ammonium phosphate } \\
\text { buffer: } 1.0 \% \\
\text { orthophosphoric acid } \\
(65: 35: 5)\end{array}$ & $\begin{array}{l}\text { Isocratic ODS C18 } \\
(250 \times 4.6 \mathrm{~mm} \text { i.d. } \\
5 \mu \mathrm{m}) \text { column }\end{array}$ & 318 & 5.637 & $5-40 \mu \mathrm{g} / \mathrm{mL}$ & $\begin{array}{c}\text { Pharmaceutical } \\
\text { dosage forms }\end{array}$ & [3] \\
\hline 2 & $\begin{array}{l}\text { HPLC/ } 20 \mathrm{mM} \\
\text { potassium dihydrogen } \\
\text { orthophosphate: } \\
\text { acetonitrile }(60: 40) \\
\text { containing } 0.1 \% \\
\text { acetic acid }\end{array}$ & $\begin{array}{c}\text { Inertsil ODS } 3 \mathrm{~V}, \\
(250 \times 4.6 \mathrm{~mm}, \\
5 \mu \mathrm{m})\end{array}$ & 318 & 5.4 & $0.05-15.00 \mu \mathrm{g} / \mathrm{mL}$ & $\begin{array}{l}\text { Plasma } \\
\text { samples }\end{array}$ & {$[4]$} \\
\hline 4 & $\begin{array}{l}\text { HPTLC/chloroform- } \\
\text { methanol, } 10+0.5 \\
(\mathrm{v} / \mathrm{v})\end{array}$ & $\begin{array}{c}\text { TLC aluminium } \\
\text { plates precoated } \\
\text { with silica gel } \\
60 \mathrm{~F}-254\end{array}$ & 317 & - & 200 and 1000 ng. & STZ tablets & {$[5]$} \\
\hline 5 & $\begin{array}{l}\text { HPTLC/toluene: } \\
\text { acetonitrile }(60: 40 \text {, } \\
\text { v/v) }\end{array}$ & $\begin{array}{c}\text { TLC aluminium } \\
\text { plates precoated } \\
\text { with silica gel } \\
60 \mathrm{~F}-254 \\
\end{array}$ & 314 & - & $100-500 \mathrm{ng} / \mathrm{spot}$ & $\begin{array}{l}\text { Bulk drug and } \\
\text { formulations }\end{array}$ & {$[6]$} \\
\hline 7 & $\begin{array}{l}\text { Spectrophotometric } \\
\text { estimation: } \\
\text { Method A: absorption } \\
\text { maxima method } \\
\text { Method B: first order } \\
\text { derivative spectroscopy } \\
\text { Method C: area under } \\
\text { curve method }\end{array}$ & - & $\begin{array}{l}\text { Method A-320, } \\
\text { Method B-290, } \\
\text { and Method } \\
\text { C-325-315 nm }\end{array}$ & - & $\begin{array}{l}5-35 \mu \mathrm{g} / \mathrm{mL} \text { for } \\
\text { Method } \mathrm{A} \text { and } \\
5-40 \mu \mathrm{g} / \mathrm{mL} \text { for } \\
\text { Method B and } \\
\text { Method C }\end{array}$ & $\begin{array}{l}\text { STZ tablet } \\
\text { formulation }\end{array}$ & {$[7]$} \\
\hline 9 & $\begin{array}{l}\text { Simultaneous } \\
\text { estimation of Ofloxacin } \\
\text { and STZ } \\
\text { RP-HPLC/ } 20 \mathrm{mM} \\
\text { potassium dihydrogen } \\
\text { phosphate: acetonitrile } \\
\text { in the ratio of } 60: 40 \\
(\mathrm{v} / \mathrm{v}) \text { containing } 0.1 \% \\
\text { glacial acetic acid }\end{array}$ & $\begin{array}{l}\text { Kromasil C18 } \\
\text { column }(250 \times \\
4.6 \mathrm{~mm}, 5 \mu \mathrm{m})\end{array}$ & 318 & $\begin{array}{c}\text { Ofloxacin } \sim 2.29 \\
\text { STZ } \sim 4.80\end{array}$ & $\begin{array}{l}1.5 \text { to } 3.6 \mu \mathrm{g} / \mathrm{mL} \\
\text { and } 1.0 \text { to } \\
2.4 \mu \mathrm{g} / \mathrm{mL}, \mathrm{STZ} \\
\text { and Ofloxacin, } \\
\text { respectively }\end{array}$ & $\begin{array}{l}\text { Ofloxacin and } \\
\text { STZ tablets }\end{array}$ & {$[8]$} \\
\hline 10 & $\begin{array}{l}\text { Simultaneous } \\
\text { estimation of Ofloxacin } \\
\text { and STZ } \\
\text { RP-HPLC/acetonitrile: } \\
\text { phosphate buffer }(\mathrm{pH} 3) \\
\text { in ratio of } 35: 65(\mathrm{v} / \mathrm{v})\end{array}$ & $\begin{array}{c}\text { HiQSil C18W } \\
(250 \mathrm{~mm} \times 4.6 \mathrm{~mm} \\
\text { i.d., } 5 \mu \mathrm{m})\end{array}$ & $\begin{array}{c}296 \mathrm{~nm} \\
\text { For Ofloxacin } \\
\text { and } 320 \mathrm{~nm} \text { for } \\
\text { STZ. }\end{array}$ & $\begin{array}{l}\text { Ofloxacin-2.85 } \\
\text { STZ-6.28, }\end{array}$ & $\begin{array}{c}5-50 \mu \mathrm{g} / \mathrm{mL}, \mathrm{STZ} \\
\text { and Ofloxacin }\end{array}$ & $\begin{array}{l}\text { Ofloxacin and } \\
\text { STZ tablets }\end{array}$ & {$[9]$} \\
\hline 11 & $\begin{array}{l}\text { RP- } \\
\text { HPLC/orthophosphoric } \\
\text { acid buffer, pH 3: } \\
\text { acetonitrile }(60: 40) \\
(\mathrm{v} / \mathrm{v})\end{array}$ & $\begin{array}{c}\text { Hypersil C18 } \\
\text { column }(250 \mathrm{~mm} \times \\
4.6 \mathrm{~mm}, 5 \mu \mathrm{m})\end{array}$ & $320 \mathrm{~nm}$ & 4.3 & 10 to $60 \mathrm{ppm}$ & $\begin{array}{l}\text { Stability } \\
\text { indicating } \\
\text { method }\end{array}$ & $\begin{array}{l}\text { Present } \\
\text { work }\end{array}$ \\
\hline
\end{tabular}

the range from 10 to $60 \mu \mathrm{g} / \mathrm{mL}$. Twenty microliters of each concentration was injected in duplicate into the HPLC system. The response was read at $320 \mathrm{~nm}$, and the corresponding chromatograms were recorded. The regressions of the plots were computed by least square regression method.

The LOQ and LOD were based on the standard deviation of the response and the slope of the constructed calibration curve as described in International Conference on Harmonization guidelines [10].

2.7.3. Method Precision and Ruggedness (Intermediate Precision). Precision of the method was performed as intraday precision and interday precision. To study the intraday precision, assay was performed on 6 doses of single batch of 
TABLE 3: Results of precision study.

\begin{tabular}{lcc}
\hline Replicates & $\begin{array}{c}\text { Method precision } \\
\text { Day-1 } \\
\text { analyst-1 } \\
\text { (\% assay) }\end{array}$ & $\begin{array}{c}\text { Intermediate precision } \\
\text { Day-2 } \\
\text { analyst-2 } \\
\text { (\% assay) }\end{array}$ \\
\hline Assay-1 & 99.93 & 101.41 \\
Assay-2 & 101.26 & 100.28 \\
Assay-3 & 99.8 & 98.89 \\
Assay-4 & 101.73 & 99.22 \\
Assay-5 & 101.93 & 98.82 \\
Assay-6 & 98.4 & 101.81 \\
\hline Average & 100.5083 & 100.0717 \\
Standard deviation (SD) & 1.3682 & 1.30726 \\
\% relative standard & 1.3612 & 1.3063 \\
deviation (\% RSD) & \multicolumn{2}{|c}{100.29} \\
\hline Average & 1.2960 \\
Standard deviation (SD) & & \\
\% relative standard & & 1.2923 \\
deviation (\% RSD) & & \\
\hline
\end{tabular}

granules and the samples were analyzed by test method. Ruggedness was carried out by changing the person and conducting precision experiment at different days. The percent relative standard deviation (\% RSD) was calculated.

2.7.4. Recovery. The accuracy of the assay method was evaluated in triplicate at three concentration levels $(80,100$, and $120 \%$ ), and the percentage recoveries were calculated. The study was carried out in triplicate at 32,40 , and $48 \mu \mathrm{g} / \mathrm{mL}$ using granules equivalent to 16,20 , and $24 \mathrm{mg}$, respectively.

2.7.5. Robustness. Robustness was evaluated by changing the flow rate by $\pm 0.2 \mathrm{~mL}$, wavelength by $\pm 2 \mathrm{~nm}$, and temperature by $\pm 5^{\circ} \mathrm{C}$ and analyzing the samples by making above changes in HPLC method. The factors of robustness study are summarized in Table 1.

2.7.6. System Suitability. System suitability testing is used to verify that the precision/reproducibility of the system is adequate for the analysis to be performed. Parameters such as theoretical plates, tailing factor, and reproducibility (\% RSD for area of five replicates) were determined. Five replicate injections of the standard solution were made into HPLC system. The mean, SD, and \% RSD were calculated.

2.7.7. Solution Stability. The solutions stability was analyzed over a period of 24 hours, verifying the response of the standard and sample solution stored at room temperature.

2.7.8. Forced Degradation Studies/Specificity. The study was intended to ensure the effective separation of Satranidazole and its degradation peaks of formulation ingredients at the retention time of Satranidazole. Forced degradation studies were performed to evaluate the stability indicating properties and specificity of the method.
All solutions for use in stress studies were prepared at an initial concentration of $1 \mathrm{mg} / \mathrm{mL}$ of Satranidazole and refluxed for $30 \mathrm{~min}$ at $80^{\circ} \mathrm{C}$. All samples were then diluted in mobile phase to give a final concentration of $40 \mu \mathrm{g} / \mathrm{mL}$ and filtered before injection.

Acid decomposition was carried out in $0.1 \mathrm{M} \mathrm{HCl}$ and alkaline degradation was conducted using $0.1 \mathrm{M} \mathrm{NaOH}$ and refluxed for $30 \mathrm{~min}$ at $80^{\circ} \mathrm{C}$. After cooling the solutions were neutralized and diluted with mobile phase.

Solutions for oxidative stress studies were prepared using $3 \% \mathrm{H}_{2} \mathrm{O}_{2}$ at a concentration of $1 \mathrm{mg} / \mathrm{mL}$ of Satranidazole and after refluxation for $30 \mathrm{~min}$ at $80^{\circ} \mathrm{C}$ on the thermostat the sample solution was cooled and diluted accordingly with the mobile phase.

For thermal stress testing, the drug solution $(1 \mathrm{mg} / \mathrm{mL})$ was heated in oven at $80^{\circ} \mathrm{C}$ for $30 \mathrm{~min}$, cooled, and used. The drug solution $(1 \mathrm{mg} / \mathrm{mL})$ for photo stability testing was exposed to UV light for $4 \mathrm{~h}$ UV light chamber $(365 \mathrm{~nm})$ and analyzed.

2.7.9. Market Sample Analysis. The solutions extracted from the marketed formulations were also injected into the HPLC system and the peak area of the chromatograms was noted. The proposed method was applied for the determination of STZ tablets (Satrogyl tablet, $300 \mathrm{mg}$ ).

\section{Results and Discussion}

No stability indicating method is available in the official compendia using HPLC for analyzing Satranidazole in dosage forms till now. The present proposed method was compared with the reported methods in the literature and shown in Table 2. The complete separation of the analytes was accomplished in less than $7 \mathrm{~min}$ and the method can be successfully applicable to perform long-term and accelerate stability studies of Satranidazole formulations.

The concentration of acetonitrile and buffer was optimized to give symmetric peak with short run time. The mobile phase Orthophosphoric acid buffer, pH 3 (adjusted using triethylamine), Acetonitrile (60:40), was found to be better solvent system. Under optimized chromatographic conditions as mentioned above, a steady baseline was recorded, when standard solutions of STZ were injected and the chromatograms were recorded. The retention time of STZ was found to be about $4.3 \mathrm{~min}$ which allowed rapid determination of STZ in developed granular dosage form. This procedure was repeated for the sample solutions of taste masked granules of STZ. The peak area of standard solutions and sample solutions was calculated and \% assay values were determined.

There was no interference of placebo and blank solution peaks at the retention time of STZ in standard and sample chromatogram. Retention time of STZ was not affected. The representative chromatograms of blank, placebo, standard and sample are shown in Figures 3, 4, 5, and 6, respectively.

The linearity was performed in triplicate. The calibration curve was found to be linear over the concentration range of $10-60 \mu \mathrm{g} / \mathrm{mL}$ and the regression equation obtained was 
TABLE 4: Results of recovery studies.

\begin{tabular}{|c|c|c|c|c|c|}
\hline Sr. number & Levels (\%) & $\begin{array}{c}\text { Granules equivalent to } \\
X \mathrm{mg} \text { of STZ added } X \mathrm{mg}\end{array}$ & $\begin{array}{l}\text { Amount of STZ } \\
\text { recovered (mg) }\end{array}$ & $\%$ recovery ${ }^{*}$ & $\begin{array}{l}\% \text { relative standard } \\
\text { deviation (\% RSD) }\end{array}$ \\
\hline 1 & 80 & 16 & 15.9597 & 99.69 & 0.4965 \\
\hline 2 & 100 & 20 & 20.4382 & 102.155 & 0.745 \\
\hline 3 & 120 & 24 & 24.3959 & 101.555 & 0.7119 \\
\hline
\end{tabular}

${ }^{*}$ Mean of three determinations.

TABLE 5: Results of robustness study.

\begin{tabular}{|c|c|c|c|c|}
\hline Chromatographic conditions & Normal & Variation & $\%$ assay & $\%$ relative standard deviation (\% RSD) \\
\hline \multirow{2}{*}{ Wavelength (nm) } & \multirow{2}{*}{320} & 318 & 100.00 & 0.5939 \\
\hline & & 322 & 101.01 & 0.63 \\
\hline \multirow{2}{*}{ Column temperature $\left({ }^{\circ} \mathrm{C}\right)$} & \multirow{2}{*}{25} & 20 & 98.25 & 0.2734 \\
\hline & & 30 & 100.26 & 0.2101 \\
\hline \multirow{2}{*}{ Flow rate $(\mathrm{mL} / \mathrm{min})$} & \multirow{2}{*}{1} & 0.8 & 100.295 & 0.6133 \\
\hline & & 1.2 & 100.535 & 0.6541 \\
\hline
\end{tabular}

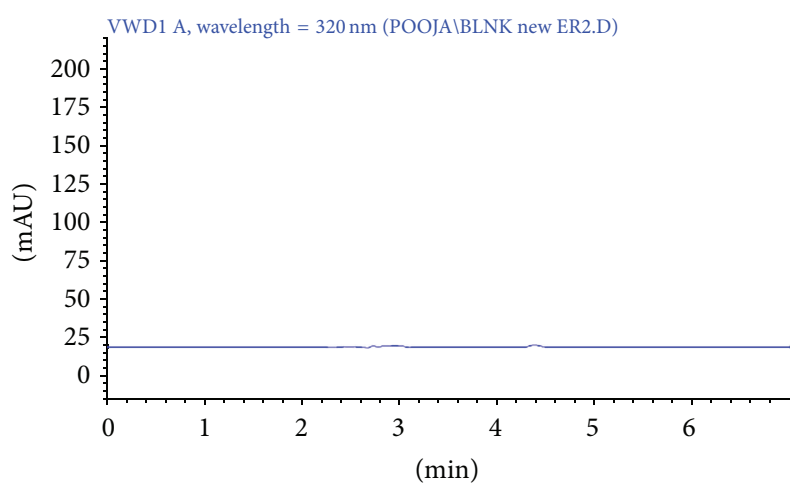

FIgURE 3: Chromatogram of blank solution.

$y=44.203 x+50.893$ with correlation coefficient of 0.999 . The LOD was found to be $1.52 \mu \mathrm{g} / \mathrm{mL}$ and the LOQ was found to be $4.62 \mu \mathrm{g} / \mathrm{mL}$. Linearity graph is shown in Figure 7 .

The results of method precision and intermediate precision (Ruggedness) are summarized in Table 3. The \% RSD value was found to be less than 2 indicating that the method is precise and rugged.

Recovery experiments were done to determine the accuracy of the method. The results are shown in Table 4 . The data indicated good reproducibility.

It was observed that there were no marked changes in chromatograms and the method was found to be reliable during normal usage due to small changes in some analytical parameters like change in wavelength, flow rate, and temperature, which demonstrated that the developed method was robust in nature. Table 5 represents the results of robustness study.

The standard solution was used as a system suitability solution. The acceptance criteria for system suitability study are as follows. Relative standard deviation (\% RSD) of the peak area responses for STZ from five standard solution injections should not be not more than $2.0 \%$. The tailing factor

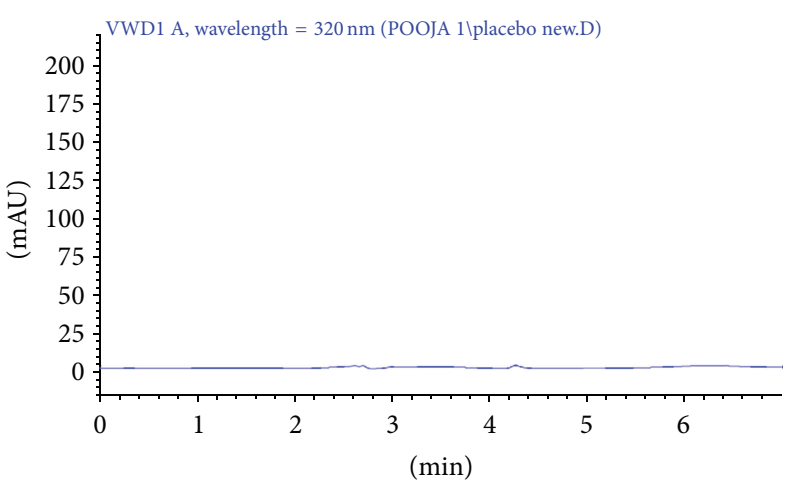

FIGURE 4: Chromatogram of placebo solution.

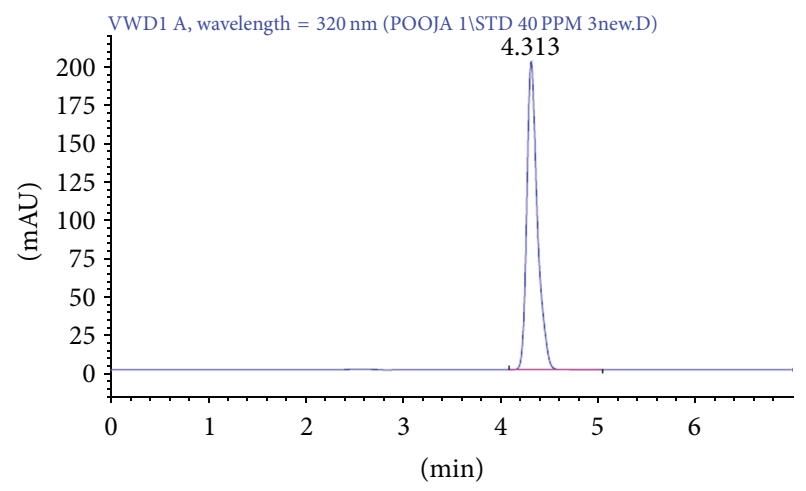

Figure 5: Chromatogram of standard solution.

and theoretical plate counts in standard solution should not be more than 2.0 and less than 2000, respectively.

The theoretical plates obtained were 8477 (more than 2000) and tailing factor was 1.37 (less than 2) for the STZ peak. The $\%$ RSD for five replicate injections was found to be less than 2 . The results of system suitability study are represented in Table 6. 
TABLE 6: Summary of system suitability results.

\begin{tabular}{|c|c|c|c|c|}
\hline Determination & Retention time & Area & Theoretical plates & Tailing factor \\
\hline 1 & 4.299 & 1499.1 & 8440 & 1.3780 \\
\hline 2 & 4.315 & 1486.8 & 8512 & 1.4000 \\
\hline 3 & 4.313 & 1495.9 & 8399 & 1.3658 \\
\hline 4 & 4.315 & 1525.3 & 8595 & 1.3770 \\
\hline 5 & 4.314 & 1492 & 8441 & 1.3658 \\
\hline Mean & 4.3112 & 1499.8 & 8477.4 & 1.3773 \\
\hline Standard deviation (SD) & 0.0068 & 14.964 & 77.2936 & 0.0139 \\
\hline$\%$ relative standard deviation (\% RSD) & 0.1593 & 0.9977 & 0.9117 & 1.0141 \\
\hline
\end{tabular}

TABLE 7: Results of forced degradation studies.

\begin{tabular}{lcc}
\hline $\begin{array}{l}\text { Degradation } \\
\text { mechanism }\end{array}$ & $\begin{array}{c}\text { STZ main peak } \\
\text { retention time }(\mathrm{min})\end{array}$ & $\begin{array}{c}\text { Degradation peak } \\
\text { retention time }(\mathrm{min})\end{array}$ \\
\hline Acid hydrolysis & 4.378 & 3.991 \\
Base hydrolysis & 4.369 & 3.228 and 3.383 \\
$\mathrm{H}_{2} \mathrm{O}_{2}$ oxidation & 4.266 & No peak \\
$\mathrm{UV}$ radiation & 4.273 & No peak \\
Heat & 4.30 & No peak \\
\hline
\end{tabular}

TABLE 8: Analysis of STZ commercial formulation.

\begin{tabular}{lcccc}
\hline $\begin{array}{l}\text { Sample } \\
\text { number }\end{array}$ & Formulation & $\begin{array}{c}\text { Labeled } \\
\text { claim }(\mathrm{mg})\end{array}$ & $\begin{array}{c}\text { Amount } \\
\text { found (mg) }\end{array}$ & Recovery (\%) \\
\hline 1 & $\begin{array}{c}\text { Satrogyl } \\
\text { tablets }\end{array}$ & 300 & 294.63 & 98.21 \\
\hline
\end{tabular}

It was found that during the acidic degradation one major degradant was observed at retention time 3.991, whereas in base degradation two degradants were observed at retention times 3.228 and 3.383, without interfering the elution of drug peak (about 4.3 mins). No significant degradation was observed during heat, $\mathrm{UV}$, and $\mathrm{H}_{2} \mathrm{O}_{2}$ degradation. The results of forced degradation studies are shown in Table 7.

Solution stability data indicated that the solution was stable for 24 hours at $25^{\circ} \mathrm{C}$. The result of assay of the marketed tablet of STZ is shown in Table 8.

The statistical evaluation of the proposed method revealed good linearity, reproducibility, and its validation for different parameters.

\section{Conclusion}

The previously mentioned developed HPLC method helps in accurate quantitative determination of STZ in taste masked STZ granules as well as tablets. It includes easy method for mobile phase preparation by using simple reagents and solvents. The method was found to be rapid as the retention time of STZ was about $4.3 \mathrm{~min}$. The method was found to be linear, precise, accurate, stability indicating, specific, and reproducible from the results of validation. The above stated method can be successfully used for the assay of drug from its granular and tablet formulations in routine analysis.

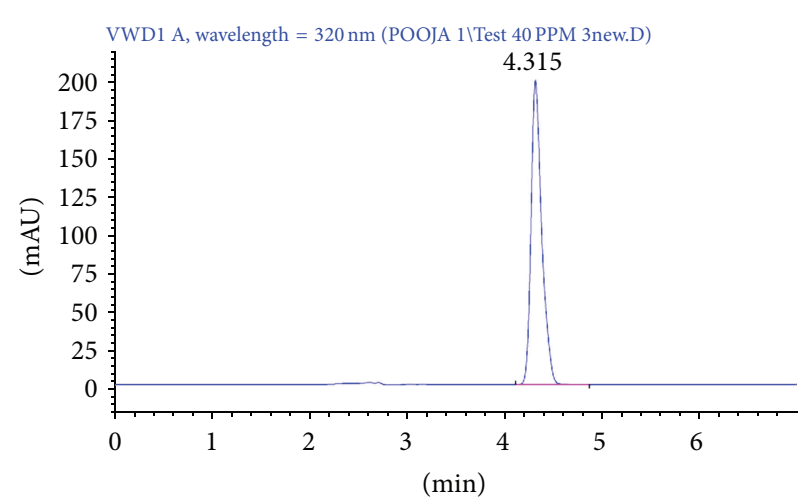

FIGURE 6: Chromatogram of sample solution.

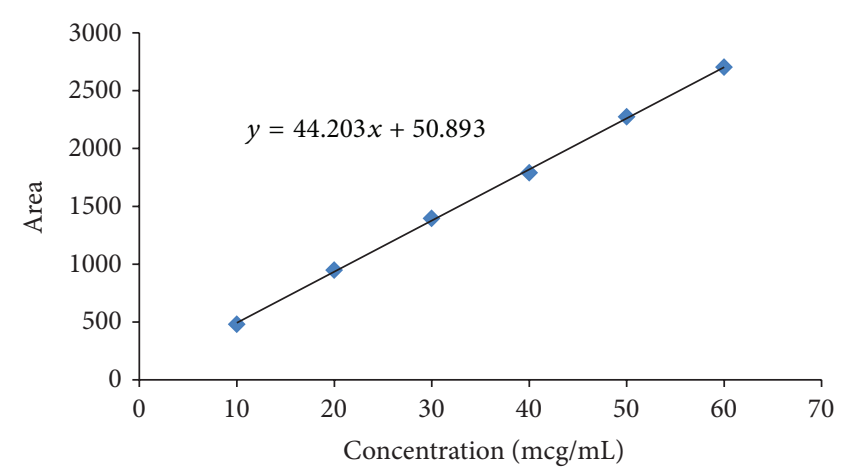

FIGURE 7: Linearity curve of STZ.

\section{Conflict of Interests}

The authors declare that there is no conflict of interests regarding the publication of this paper.

\section{Acknowledgment}

The authors are very much thankful to Dr. P. S. Gide, Principal of Hyderabad Sindh National Collegiate Boards (HSNCB's), Dr. L. H. Hiranandani College of Pharmacy, Ulhasnagar, for his continuous support, guidance, and encouragement. 


\section{References}

[1] A. Pargal, C. Rao, K. K. Bhopale, K. S. Pradhan, K. B. Masani, and C. L. Kaul, "Comparative pharmacokinetics and amoebicidal activity of metronidazole and satranidazole in the golden hamster, Mesocricetus auratus," Journal of Antimicrobial Chemotherapy, vol. 32, no. 3, pp. 483-489, 1993.

[2] D. M. Parmar and S. P. Jadav, "The concept of personal drugs in the undergraduate pharmacology practical curriculum," Indian Journal of Pharmacology, vol. 39, no. 3, pp. 165-167, 2007.

[3] K. Kiran Kumar and R. Venkata Nadh, "Reverse phase high performance liquid chromatographic method for the determination of satranidazole in pharmaceutical formulations," Rasayan Journal of Chemistry, vol. 4, no. 3, pp. 681-685, 2011.

[4] S. R. Shinde, S. I. Bhoir, N. S. Pawar, A. M. Bhagwat, and A. S. Ghumatkar, "High-Performance liquid chromatographic analysis of nitroimidazole derivative satranidazole using a liquid extraction method," International Journal of PharmTech Research, vol. 2, no. 3, pp. 2032-2037, 2010.

[5] J. Lalla, P. Hamrapurkar, R. Anu, and T. Wadhwa, "Highperformance thin-layer chromatographic determination of satranidazole in its dosage form," Journal of Planar Chromatography, vol. 16, no. 6, pp. 447-450, 2003.

[6] M. B. Patel, K. M. Patel, G. S. Patel, B. N. Suhagia, and A. M. Prajapati, "Development and validation of a stability-indicating HPTLC-densitometric method for satranidazole," Journal of Liquid Chromatography and Related Technologies, vol. 30, no. 16, pp. 2459-2471, 2007.

[7] S. B. Wankhede, A. Prakash, and S. Chitalange, "Simultaneous spectrophotometric estimation of Satranidazole in tablet dosage form," Research Journal of Pharmacy and Technology, vol. 1, no. 4, pp. 441-443, 2008.

[8] R. Shinde Sachin, I. B. Suvarna, S. P. Namdev, B. Y. Suman, and M. B. Ashok, "Simultaneous estimation of satranidazole and ofloxacin in tablet dosage form by high performance liquid chromatography," E-Journal of Chemistry, vol. 7, no. 1, pp. 198202, 2010.

[9] V. P. Godse, Y. S. Bafana, S. Y. Deshapande, M. R. Vyas, and A. V. Bhosale, "Validated stability-indicating hplc method for simultaneous estimation of Ofloxacin and Satranidazole from pharmaceutical dosage form," International Journal of Applied Biology and Pharmaceutical Technology, vol. 1, no. 3, pp. 12201229, 2010.

[10] "ICH validation of analytical procedures: text and methodology Q2 (R1)," in Proceedings of International Conference on Harmonization, 2005. 

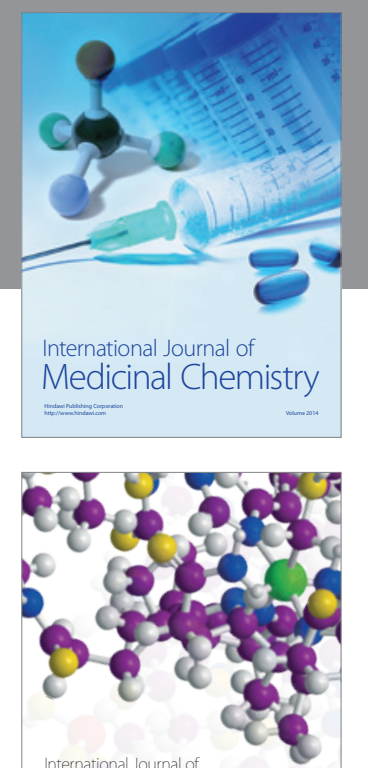

\section{Carbohydrate} Chemistry

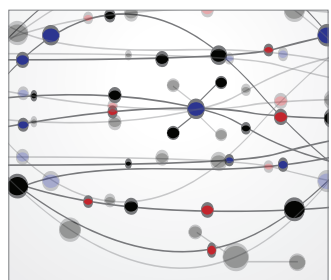

The Scientific World Journal
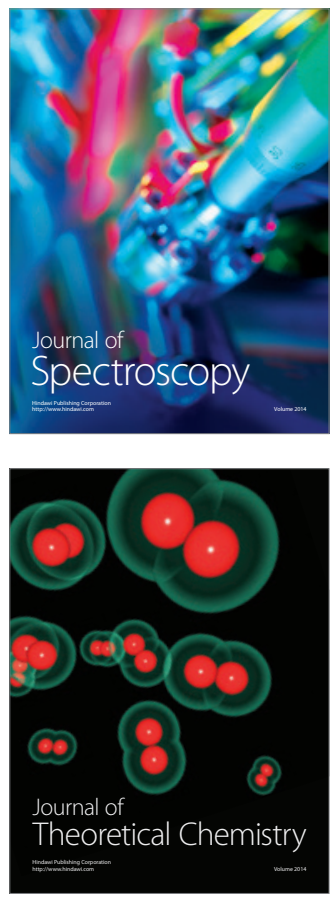
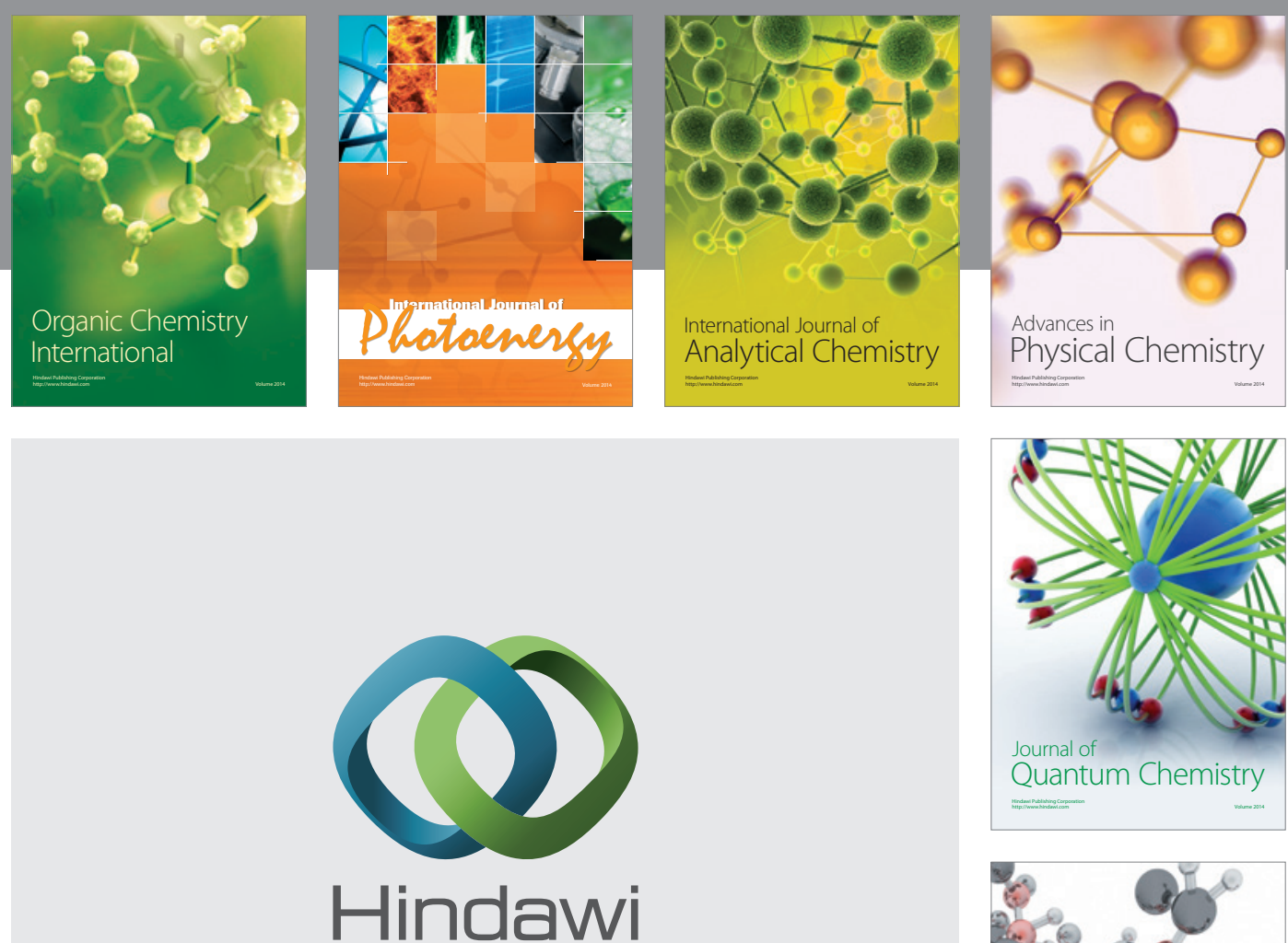

Submit your manuscripts at

http://www.hindawi.com

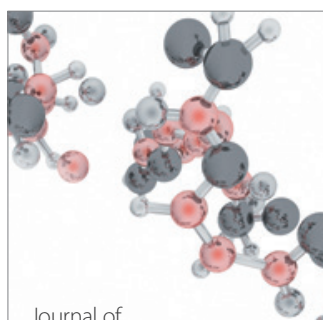

Analytical Methods

in Chemistry

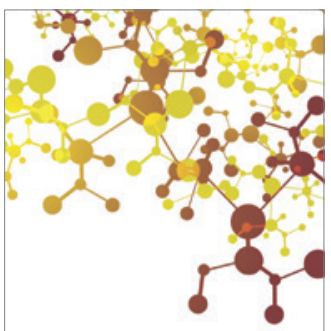

Journal of

Applied Chemistry

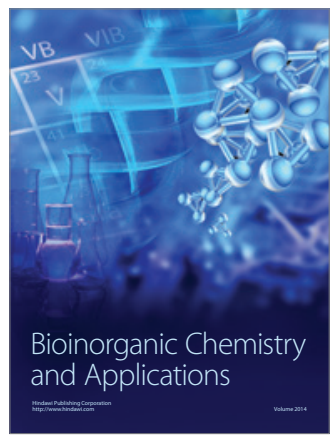

Inorganic Chemistry
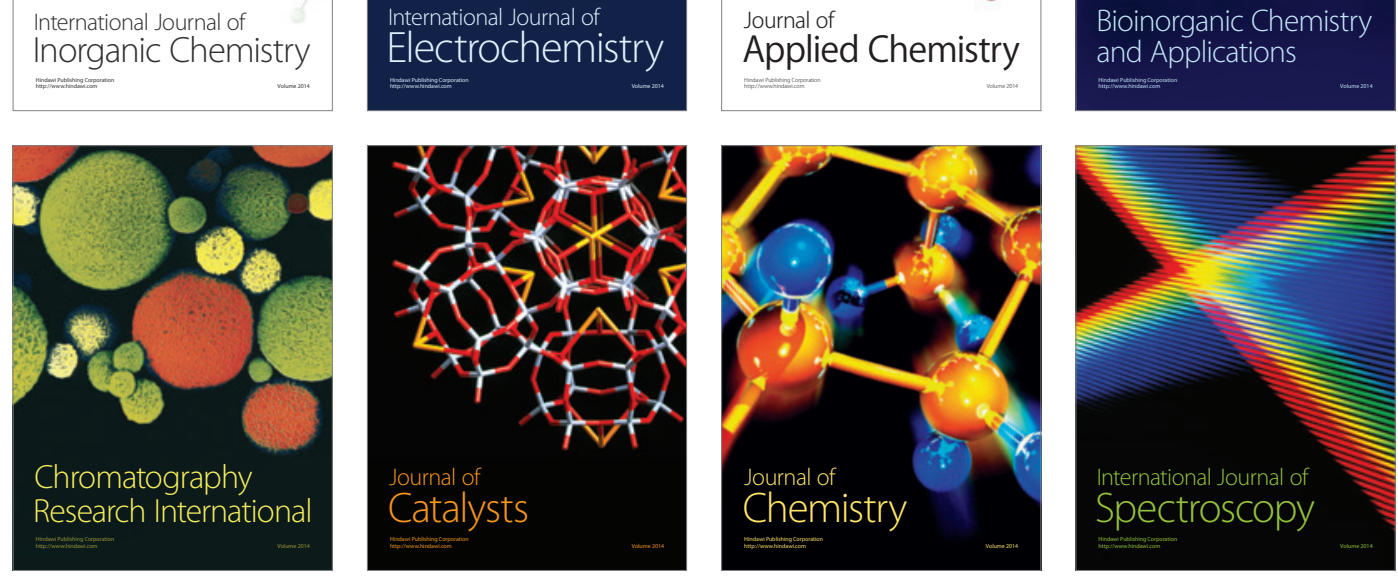